\title{
Problems Perceived by Agripreneurs of Varanasi District (U.P.)
}

\author{
Mohammad Hashim* and A. K. Singh \\ Department of Extension Education, Institute of Agricultural Sciences, \\ Banaras Hindu University, (U.P.), India \\ *Corresponding author
}

\section{A B S T R A C T}

\section{Keywords \\ Agripreneurs, KVK, Marketing, Problem \\ Article Info \\ Accepted: \\ 07 November 2020 \\ Available Online: \\ 10 December 2020}

The present investigation was carried out to elucidate the problems perceived by flower agripreneurs of Varanasi district of Uttar Pradesh. The findings of the study revealed that cent percent agripreneurs indicated unorganized entrepreneurs as the main socio-economic problem, non availability of quality planting material in nearby market as the main technological problem, distant location of $\mathrm{KVK}$ as the main institutional problem, unavailability of timely information about different governmental schemes as the main management problem and lack of price regulating agency as the main marketing problem.

\section{Introduction}

Indian economy is basically an agrarian economy. On 2.4 per cent of world land, India is managing 17.5 per cent of world population. At the time of independence, more than half of the national income was contributed by agriculture along with more than 70 per cent of total population depending on agriculture (Pandey, 2013). Activities like diversification, value addition, precision farming, high-tech agriculture, Agripreneurship, global marketing, organic farming etc., are gradually getting due attention of people involved on redefining agriculture. Growing of flowers and ornamental crops is a rapid expanding global enterprise in today's world (Prasad and Kumar, 2010).
Like all other sectors, agripreneurs also have to face certain problems which decide the effectiveness of their agripreneurial ability and success. These problems may be related to different dimensions of agriprenurial activities ranging from socio-economic to marketing including technological, institutional and management problems. The present investigation is an attempt to explore the same.

\section{Materials and Methods}

The study was conducted in Varanasi district of Uttar Pradesh. Out of eight blocks of the district, two blocks with maximum area under flower cultivation were selected. Top ten villages in terms of area under flower 
cultivation were identified from each block and thus, in total twenty villages were selected purposively. The respondents from each village were selected randomly by means of proportionate random sampling. In total 200 respondents were selected (75 from Kashi Vidyapeeth blok and 125 from Chiraigaon block).

\section{Results and Discussion}

\section{Problems faced by the agripreneurs}

Table 1 reveals that cent percent of the respondents indicated unorganized agripreneurs as the main socio-economic problems followed by high initial cost of flower cultivation $(29.00 \%)$, complex procedure of loan (27.00\%), dominance of a particular caste in the government development schemes (25.00\%), lack of credit and insurance facilities $(20.50 \%)$, high cost of interculture operation, low prestige with flower cultivation (17.00 \%), unavailability of loan (15.00\%), higher capital investment $(12.50 \%)$, high cost of flower cultivation $(6.00 \%)$ while none of the respondents indicated promptness of payment as the one of the socio-economic problems.

Majority (31.50 \%) of the respondents indicated non availability of quality planting material in nearby market as the main technological problems followed by lack of awareness regarding new updates in floriculture $(25.00 \%)$, non availability of recommended insecticides and pesticides in the market $(23.50 \%)$, non availability of subsidised fertilizers in required quantity $(22.00 \%)$ and lack of knowledge about scientific cultivation $(8.00 \%)$. Majority $(33.50 \%)$ of the respondents indicated distant location of the KVK as the main institutional problems followed by distant location of DHO (30.50\%), complications in government subsidies $(26.00 \%)$, lack of training on scientific flower cultivation $(25.50 \%)$, complication in claiming and securing sum assured $(23.50 \%)$, distant location of Agricultural institute/college $(23.50 \%)$ and lack of extension support and services (22.50 $\%)$.

Table.1 Distribution of agripreneurs faced by the agripreneurs $(n=200)$

\begin{tabular}{|l|c|c|}
\hline \multicolumn{1}{|c|}{ Problems } & F & $\%$ \\
\hline A. Socio economic problems & 200 & 100.00 \\
\hline Unorganized agripreneurs & 34 & 17.00 \\
\hline Low prestige with flower cultivation & 43 & 21.50 \\
\hline Lack of credit and insurance facilities & 25 & 12.50 \\
\hline Higher capital investment. & 12 & 6.00 \\
\hline High initial cost of flower cultivation & 58 & 29.00 \\
\hline High cost of insecticide and pesticide & 20 & 10.00 \\
\hline High cost in transportation & 41 & 20.50 \\
\hline High cost of intercultural operation & 0 & 0.00 \\
\hline Promptness of payment & 50 & 25.00 \\
\hline $\begin{array}{l}\text { Dominance of a particular caste in the government development } \\
\text { schemes }\end{array}$ & & \\
\hline Unavailability of loan & 30 & 15.00 \\
\hline Complex procedure of loan & 54 & 27.00 \\
\hline B. Technological problems & & \\
\hline
\end{tabular}




\begin{tabular}{|l|l|l|}
\hline Non availability of quality planting material in nearby market. & 63 & 31.50 \\
\hline Lack of awareness regarding new updates in floriculture & 50 & 25.00 \\
\hline $\begin{array}{l}\text { Non availability of recommended insecticides and pesticides in } \\
\text { the market. }\end{array}$ & 47 & 23.50 \\
\hline Non availability of subsidised fertilizers in required quantity. & 44 & 22.00 \\
\hline Lack of knowledge about scientific cultivation. & 16 & 8.00 \\
\hline C. Institutional problems & 45 & 22.50 \\
\hline Lack of extension support and services & 51 & 25.50 \\
\hline Lack of training on scientific flower cultivation. & 52 & 26.00 \\
\hline Complications in government subsidies. & 47 & 23.50 \\
\hline Complication in claiming and securing sum assured. & 61 & 30.50 \\
\hline Distant location of DHO & 67 & 33.50 \\
\hline Distant location of KVK & 47 & 23.50 \\
\hline Distant location of Agricultural institute/college. & & \\
\hline D. Management problems & 70 & 35.00 \\
\hline $\begin{array}{l}\text { Unavailability of timely information about different } \\
\text { governmental schemes }\end{array}$ & 60 & 30.00 \\
\hline Inadequate input availability & 40 & 20.00 \\
\hline Insufficient availability of labour & 67 & 33.50 \\
\hline Insufficient technical knowledge about scientific cultivation. & 50 & 25.00 \\
\hline High crop damage due to insect/pests & 62 & 31.00 \\
\hline Difficulty in maintaining records & 60 & 30.00 \\
\hline $\begin{array}{l}\text { Shrinking area under cultivation due to dominance of nuclear } \\
\text { family }\end{array}$ & & \\
\hline E. Marketing problems & & \\
\hline Too much fluctuation in price. & 81 & 40.50 \\
\hline Lack of price regulating agency & 85 & 42.50 \\
\hline Exploitation by middlemen & 67 & 33.50 \\
\hline Distant location of market. & 79 & 39.50 \\
\hline Unsteady demand of flowers in the market & 70 & 35.00 \\
\hline Costly means of transportation & 26 & 13.00 \\
\hline Lack of proper market forecasting & 70 & 35.00 \\
\hline
\end{tabular}

Table.2 Distribution of agripreneurs according problems faced by the agripreneurs $(n=200)$

\begin{tabular}{|c|c|c|c|c|c|c|c|c|c|}
\hline \multirow[t]{2}{*}{ Category } & \multicolumn{3}{|c|}{$\begin{array}{c}\text { Kashi Vidyapeeth } \\
\left(\mathbf{n}_{1}=75\right)\end{array}$} & \multicolumn{3}{|c|}{$\begin{array}{c}\text { Chiraigaon } \\
\left(\mathrm{n}_{2}=125\right)\end{array}$} & \multicolumn{3}{|c|}{$\begin{array}{c}\text { Overall } \\
\left(\mathbf{n}_{1}+\mathbf{n}_{2}=200\right)\end{array}$} \\
\hline & Value & $\mathbf{F}$ & $\%$ & Value & $\mathbf{F}$ & $\%$ & Value & $\mathbf{F}$ & $\%$ \\
\hline Low & $<8.02$ & 12 & 16.00 & $<6.48$ & 17 & 13.60 & $<6.91$ & 22 & 11.00 \\
\hline Medium & $\begin{array}{l}8.02- \\
14.91\end{array}$ & 51 & 68.00 & $\begin{array}{l}6.48- \\
12.47\end{array}$ & 92 & 73.60 & $\begin{array}{l}6.91- \\
13.53\end{array}$ & 150 & 75.00 \\
\hline \multirow[t]{2}{*}{ High } & $>14.91$ & 12 & 16.00 & $>12.47$ & 16 & 12.80 & $>13.53$ & 28 & 14.00 \\
\hline & \multicolumn{3}{|c|}{$\begin{array}{c}\text { Mean }=11.47 \\
S D=3.45\end{array}$} & \multicolumn{3}{|c|}{$\begin{array}{c}\text { Mean }=9.47 \\
\mathrm{SD}=3\end{array}$} & \multicolumn{3}{|c|}{$\begin{array}{c}\text { Mean }=10.22 \\
\mathrm{SD}=3.31\end{array}$} \\
\hline
\end{tabular}


Majority (35.00\%) indicated unavailability of timely information about different governmental schemes as the main management problems followed by insufficient technical knowledge about scientific cultivation (33.50 $\%)$, difficulty in maintaining records $(31.00 \%)$, inadequate input availability $(30.00 \%)$, shrinking area under cultivation due to dominance of nuclear family $(30.00 \%)$, high crop damage due to insect/pests $(25.00 \%)$ insufficient availability of labour $(20.00 \%)$.

Majority $(42.50 \%)$ of the respondents indicated lack of price regulating agency as the main marketing constraint followed by too much fluctuations in price $(40.50 \%)$, distant location of market (39.50\%), unsteady demand of flower in the market $(35.00 \%)$, lack of proper market forecasting $(35.00 \%)$, exploitation by middlemen $(33.50 \%)$ and costly means of transportation $(42.50 \%)$.

Table 2 reveals that majority $(76.00 \%)$ of the respondents of Kashi Vidyapeeth block belonged to medium category of problems followed by equal percentage $(16.00 \%)$ of respondents who belonged to low and high category of problems. Majority (73.60 \%) of the respondents from Chiraigaon belonged to medium category of problems followed by low category $(13.60 \%)$ and high category $(12.80 \%)$ of problems. Overall, majority $(75.00 \%)$ of the respondents belonged to medium category of problems followed by high category $(14.00 \%)$ and low category $(11.00 \%)$ of problems.

In conclusion the order to make the farming community more strong and economically sound, it is very necessary that their agripreneurial characteristics should be motivated. All the possible reasons that are affecting agripreneurial behaviour must be taken into account and resolved timely. This will motivate other farmers to take agripreneurship and become self sufficient in long run.

\section{References}

Alex, L. (2011). A review and analysis of policies on farmers' entrepreneurship development. A publication of PELUM, Misereor. Pp. 1-55.

Bairwa, S.L., Kalia, A., Meena, L. K., Lakra, K. and Kushwaha, S. (2014). Agribusiness management education: A review on employment opportunities. International Journal of Scientific and Research Publications, 4 (2) 1-4.

Dollinger, M. J. (2003). Entrepreneurship: Strategies and resources. New Jersey: Pearson International Edition.

Keshava, A. K., Mehta, and Gill, H. K. (2010). Management of economic activities in women self-help groups. Indian Research Journal of Extension Education, 10(1): 58-61.

Pandey, G. (2013). Agripreneurship Education and Development: Need of the Day. Asian Resonance. II (IV), 155-157.

Keshava, A. K., Mehta and Gill H. K. (2010). Management of economic activity in women self-help groups. Indian Research Journal of Extension Education, 10 (1), 58-61

Singh, A. P. (2013 a). Factors influencing entrepreneurship among farming community in Uttar Pradesh, Journal of Arts, Science and Commerce, IV (3), 114121.

Singh, A. P. (2013 b). Strategies for developing Agripreneurship among farming community in Uttar Pradesh, India. Academia: An International Multidisciplinary Research Journal, 3 (11), 1-12.

\section{How to cite this article:}

Mohammad Hashim and Singh, A. K. 2020. Problems Perceived by Agripreneurs of Varanasi District (U.P.). Int.J.Curr.Microbiol.App.Sci. 9(12): 640-643. doi: https://doi.org/10.20546/ijcmas.2020.912.076 